\title{
Perbandingan Zakat Produktif dan Zakat Konsumtif dalam Meningkatkan Kesejahteraan Mustahik
}

\section{The Comparative Study Between Productive and Consumptive Based Zakat}

\author{
Khalifah Muhamad Ali ${ }^{1}$, Nydia Novira Amalia ${ }^{2}$, Salahuddin El Ayyubi ${ }^{3}$ \\ ${ }^{1}$ Dosen Institut Pertanian Bogor, Email khalifahma@gmail.com \\ 2Alumnus Program Studi Ilmu Ekonomi Syariah, Institut Pertanian Bogor, Email noviranydia@gmail.com \\ ${ }^{3}$ Dosen Institut Pertanian Bogor, Email 22djibran@gmail.com
}

\begin{abstract}
This study aims to compare the effectiveness of productive and consumptive zakat distribution in poverty alleviation. This study uses a CIBEST (Center of Islamic Business and Economics Studies) model which measures not only the material aspect of the poverty, but also the spiritual aspect of the respondents. The results proves that both zakat distribution types can increase welfare as well as reduce poverty of mustahik. Productive zakat can alleviate poverty more than consumtive zakat.
\end{abstract}

Keywords: mustahik, productive and consumptive zakat, welfare

\begin{abstract}
Abstrak. Penelitian ini bertujuan untuk membandingkan efektivitas penyaluran zakat secara produktif dengan penyaluran zakat secara konsumtif dalam meningkatkan kesejahteraan mustahik. Penelitian ini menggunakan Model CIBEST (Center of Islamic Business and Economics Studies) yang tidak hanya mengukur kemiskinan dari aspek material, namun juga aspek spiritual responden. Hasil penelitian menunjukkan bahwa kedua cara penyaluran zakat tersebut terbukti dapat meningkatkan kesejahteraan sekaligus menurunkan kemiskinan mustahik. Zakat produktif lebih mampu meningkatkan kesejahteraan mustahik dibandingkan dengan zakat konsumtif.
\end{abstract}

Kata Kunci: kesejahteraan, mustahik, zakat produktif, zakat konsumsi

\section{Pendahuluan}

Salah satu permasalahan di Indonesia yang belum berhasil diatasi oleh pemerintah adalah tingginya tingkat kemiskinan dan tingkat kesenjangan pendapatan. Data BPS (2016) menunjukkan bahwa jumlah penduduk miskin di Indonesia berjumlah 28.51 juta jiwa atau sebesar $11.26 \%$ dari total populasi, diikuti dengan tingginya Indeks Gini di Indonesia yaitu sebesar 0.40. Islam melihat masalah kemiskinan sebagai sebuah keniscayaan dalam kehidupan (sunnatullah fil hayah). Adanya kelompok masyarakat yang berbeda-beda penghasilan sesungguhnya tidak bisa dinafikan. Islam tidak pernah berbicara bagaimana upaya untuk menghilangkan kemiskinan tetapi berbicara bagaimana mereduksi dan meminimalisir tingkat kemiskinan yang terjadi (Beik dan Arsyianti 2015b). Salah satu pilar untuk meminimalisir tingkat kemiskinan tersebut dengan mengoptimalkan pendayagunaan zakat yang potensinya diperkirakan mencapai 217 triliun per tahun (BAZNAS 2011).

Zakat adalah salah satu poin dalam rukun Islam. Oleh sebab itu, setiap muslim yang telah memenuhi kriteria tertentu wajib membayar zakat. Seorang muslim yang menolak membayar zakat dianggap sebagai orang yang telah keluar dari agama dan diancam oleh Allah dengan azab yang pedih. Sebaliknya, seorang muslim yang menunaikan zakat disebut sebagai muzaki yang berarti orang yang menyucikan jiwa dan hartanya. Muzaki disunnahkan menyalurkan zakatnya kepada organisasi pengelola zakat (amil) untuk kemudian disalurkan kepada orang yang berhak menerima zakat (mustahik). Mustahik zakat dibatasi kepada delapan golongan, dan golongan yang paling diprioritaskan adalah fakir dan miskin.

Dalam praktiknya, zakat yang dihimpun oleh amil secara umum disalurkan dalam dua bentuk, yaitu secara konsumtif (zakat konsumtif) dan produktif (zakat produktif). Hal ini sesuai dengan UndangUndang Zakat nomor 23 tahun 2011 tentang Pengelolaan Zakat (Wibisono 2015). Zakat konsumtif 
ditujukan untuk memenuhi kebutuhan dasar mustahik. Jika kebutuhan dasar mustahik telah terpenuhi, maka zakat dapat disalurkan secara produktif. Zakat konsumtif umumnya disalurkan dalam bentuk santunan fakir miskin, beasiswa pendidikan, dan pelayanan kesehatan, sedangkan zakat produktif umumnya disalurkan dalam bentuk modal usaha. Dalam banyak penelitian terdahulu, zakat produktif terbukti dapat mengurangi kemiskinan dan sekaligus dapat meningkatkan kesejahteraan.

Penelitian yang mengkaji dampak zakat produktif terhadap kemiskinan telah banyak dilakukan, seperti penelitian yang dilakukan oleh Beik di Jakarta (2009), Tsani di Lampung (2010), Hartoyo dan Purnamasari di Garut (2010), dan Anriani di Bogor (2010). Penelitian-penelitian tersebut pada umumnya menyimpulkan bahwa zakat terbukti mampu mengurangi jumlah dan persentase keluarga miskin, serta mengurangi kedalaman dan keparahan kemiskinan. Namun demikian, masih jarang dijumpai penelitian yang mengkaji dampak zakat konsumtif terhadap kemiskinan mustahik, sehingga hal ini menyebabkan timbulnya pertanyaan: bagaimana efektivitas zakat konsumtif dalam meningkatkan kesejahteraan mustahik? Berdasarkan hal tersebut, tujuan penelitian ini adalah:

1. membandingkan efektivitas zakat produktif dan zakat konsumtif dalam meningkatkan kesejahteraan mustahik, serta

2. mengidentifikasi faktor-faktor yang berpengaruh terhadap kesejahteraan mustahik dari kedua cara penyaluran dana tersebut.

\section{Tinjauan Pustaka}

\subsection{Pengertian Zakat}

Zakat dari segi bahasa berarti suci, tumbuh, berkah, dan terpuji, serta berupa harta yang diberikan oleh muzaki kepada mustahik. Hal ini berarti bahwa harta yang dikeluarkan zakatnya akan menjadi berkah, tumbuh, berkembang dan bertambah, suci dan beres (baik). Hal ini sebagaimana dinyatakan dalam surat at-Taubah ayat 103, yang artinya: "Ambillah zakat dari sebagian harta mereka, dengan zakat itu kamu membersihkan dan menyucikan mereka, dan berdoalah untuk mereka. Sesungguhnya doa kamu itu menjadi ketentraman jiwa buat mereka. Dan Allah Maha Mendengar lagi Maha Mengetahui." (Depag 2002).

Adapun golongan yang berhak menerima zakat telah diatur dalam ajaran syariat Islam, yakni terdapat delapan golongan (asnaf). Ketentuan ini diatur dalam Al-Qur'an surat At-Taubah ayat 60, yang artinya: "Sesungguhnya zakat itu hanyalah untuk orang-orang fakir, orang-orang miskin, pengurus-pengurus zakat, para muallaf yang dibujuk hatinya, untuk (memerdekakan) budak, orang-orang yang berutang, untuk jalan Allah, dan orang-orang yang diwajibkan Allah. Dan Allah lagi Maha Mengetahui lagi Maha Bijaksana." (Depag 2002).

\subsection{Organisasi Pengelolaan Zakat}

Definisi kegiatan pengelolaan zakat menurut UU Nomor 23 Tahun 2011 tentang Pengelolaan Zakat adalah kegiatan perencanaan, pengorganisasian, pelaksanaan, dan pengawasan terhadap pengumpulan, pendistribusian, dan pendayagunaan zakat. Terdapat dua bentuk Organisasi Pengelolaan Zakat, yaitu Badan Amil Zakat Nasional (BAZNAS) dan Lembaga Amil Zakat (LAZ). Kedua organisasi ini secara umum mempunyai fungsi sebagai perantara keuangan, dalam hal ini amil berperan menghubungkan muzaki dan mustahik (Wibisono 2015).

\subsection{Kesejahteraan Mustahik}

Dari delapan golongan yang berhak menerima zakat, maka kelompok fakir dan miskin adalah kelompok yang paling identik dengan isu kesejahteraan. Bahkan, dua golongan ini disebutkan lebih awal daripada 
golongan yang lain sebagai isyarat pentingnya memperhatikan mereka. Menurut Imam Mazhab yang tiga fakir adalah mereka yang tidak mempunyai harta atau penghasilan layak dalam memenuhi keperluannya seperti sandang, pangan, tempat tinggal dan segala keperluan pokok lainnya, baik untuk diri sendiri ataupun bagi mereka yang menjadi tanggungannya. Sementara yang disebut miskin adalah yang mempunyai harta atau penghasilan layak dalam memenuhi keperluannya dan orang yang menjadi tanggungannya, tapi tidak sepenuhnya tercukupi (Qardhawi 2011).

Dalam Islam, dorongan untuk memperhatikan kedua golongan ini cukup banyak ditemukan baik di dalam Al-Quran maupun Hadis. Bahkan, dianggap sebagai realisasi dari keimanan seorang muslim dan menjadi sifat orang-orang yang bertakwa Islam datang dengan berbagi macam instrument berbagi baik itu zakat, infak, wakaf, maupun sedekah sebagai upaya untuk meningkatkan kesejahteraan tidak hanya duniawi tapi juga juga berdimensi ukhrawi. Khusus untuk kewajiban zakat memiliki peran yang sangat signifikan dilihat dari berbagi sudut pandang antara lain: sebagai rukun ketiga dalam Islam, perintahnya selalu disejajarkan dengan perintah sholat, perintah zakat sangat terperinci dijelaskan oleh Rasulullah Saw. Zakat sekaligus sebagai penyebab turunnya keberkahan, tanda kesempurnaan iman seseorang, dan menjadikan masyarakat muslim sebagai satu kesatuan yang saling membantu. (El Ayyubi dan Lubis 2015).

\subsection{Penelitian Terdahulu}

Nicham (2012) meneliti mengenai zakat konsumtif dan produktif pada Bapelurzam Kabupaten Kendal dan menemukan bahwa kedua tipe zakat tersebut memiliki kekurangan masing-masing. Pada zakat konsumtif, Bapelurzam Kabupaten Kendal kurang memiliki kesesuaian dengan esensi dari zakat konsumtif itu sendiri. Hal ini terjadi karena Bapelurzam Kabupaten Kendal lebih menekankan pada aspek adanya jasa yang telah diberikan oleh orang-orang yang dimasukan ke dalam mustahik zakat. Pada zakat produktif, prakteknya kurang maksimal karena pemberian modal dalam jumlah yang kecil sehingga dampaknya kurang terlihat nyata pada mustahik.

Siswi (2016) meneliti mengenai salah satu program dari dana zakat konsumtif dan produktif, yaitu ZUM (Zakat untuk Mustahik) dan KUM (Kelompok Usaha Mandiri). Berdasarkan hasil penelitian, dana zakat yang diberikan telah mampu untuk mengubah pendapatan mereka, namun zakat yang diberikan belum mampu untuk mengubah akses pendidikan anak dan jaminan kesehatan keluarga sehingga dana zakat yang diberikan belum berperan secara maksimal terhadap kehidupan mereka. Selain itu, dana zakat yang diberikan juga belum mampu untuk merubah penerima zakat produktif melalui program KUM (Kelompok Usaha Mandiri) menjadi seorang muzaki.

Rosmawati (2014) melakukan studi deskriptif analisis mengenai pengembangan potensi zakat produktif melalui Lembaga Amil Zakat (LAZ) untuk meningkatkan kesejahteraan masyarakat. Berdasarkan studi tersebut, didapati bahwa pengembangan potensi dana zakat produktif melalui fungsi dan peranan LAZ untuk meningkatkan kesejahteraan masyarakat menurut UU Pengelolaan Zakat adalah melalui program Pembiayaan Modal Usaha bagi fakir miskin dengan menerapkan asas-asas syariat Islam sesuai dengan pendayagunaan dana zakat. Fungsi dan peranan LAZ memberikan kemandirian ekonomi kepada fakir miskin dan berperan sebagai sarana keagamaan yang meningkatkan manfaat dana zakat.

Adianti (2005) melakukan penelitian mengenai faktor-faktor yang memengaruhi kemiskinan di DKI Jakarta, dengan studi komparatif di permukiman kumuh dan tidak kumuh. Hasil penelitian menunjukan bahwa indeks kemiskinan di DKI Jakarta selama tahun 2000-2004 mengalami fluktuasi. Hasil regresi logistik mengenai faktor-faktor yang berpengaruh nyata secara positif terhadap kemiskinan yaitu, anggota rumah tangga, pengeluaran, dan jumlah tanggungan. Selanjutnya untuk faktor-faktor yang berpengaruh nyata secara negatif terhadap kemiskinan yaitu, jenis pekerjaan kepala rumah tangga, pendidikan kepala rumah tangga, dan proporsi anggota keluarga yang bekerja. 
Pratama (2015) melakukan penelitian mengenai pendayagunaan dana zakat produktif dalam mengurangi kemiskinan menggunakan CIBEST model, dengan studi kasus PT. Masyarakat Mandiri Dompet Dhuafa. Pendayagunaan dana zakat produktif mampu meningkatkan rata-rata pendapatan rumah tangga mustahik dari 874000 menjadi 2160 000. Selain itu, hal tersebut juga mampu menurukan jumlah keluarga miskin dan juga dapat mengurangi tingkat kemiskinan diukur dengan indeks kemiskinan material. Hal tersebut dapat dilihat dari insiden kemiskinan yang berkurang sebesar $49.6 \%$. Tidak hanya diukur dari indeks kemiskinan material saja, CIBEST model juga mengukur indeks kemiskinan melalui aspek spiritual. Hasil penelitian ini juga menunjukan dampak pendayagunaan dana zakat produktif yang diiringi dengan pembinaan dan pendampingan mampu menurunkan indeks kemiskinan spiritual sebesar $1.6 \%$.

\section{Metode Penelitian}

\subsection{Waktu dan Lokasi Penelitian}

Penelitian ini dilakukan di wilayah JABOTABEK, yaitu Jakarta Timur, Jakarta Selatan, Tangerang Kota, Bekasi Timur, dan Bogor Barat. Penentuan lokasi penelitian dilakukan secara sengaja (purposive) dengan pertimbangan Rumah Zakat aktif menjalankan program Senyum Mandiri (mustahik zakat produktif) dan Senyum Sehat (mustahik zakat konsumtif), dalam memberikan modal usaha dan memberikan bantuan dana untuk kesehatan. Penelitian ini dilaksanakan dari bulan Februari hingga Juli 2016.

\subsection{Jenis dan Sumber Data}

Jenis dan sumber data dikategorikan ke dalam dua bagian, yaitu data primer dan data sekunder. Data primer dikumpulkan langsung melalui pengisian kuesioner dan wawancara secara langsung kepada mustahik yang mendapatkan dana bantuan zakat. Selanjutnya, data sekunder digunakan untuk melengkapi data primer yang sudah ada dan diperoleh dari literatur atau dokumen-dokumen yang sudah tersedia baik terpublikasikan atau tidak.

\subsection{Sampel Penelitian}

Penarikan sampel dalam penelitian ini dilakukan dengan menggunakan teknik purposive atau dilakukan secara sengaja. Ukuran contoh yang diamati dalam penelitian ini berjumlah 100 responden yang dipilih secara sengaja dari daftar mustahik zakat LAZ Rumah Zakat JABOTABEK.

\subsection{Metode Analisis Data}

Metode analisis yang digunakan dalam penelitian ini adalah metode deskriptif dengan menggunakan pendekatan kuantitatif dan kualitatif. Pendekatan kuantitatif dan kualitatif dilakukan dengan pencarian data-data melalui pengisian kuesioner dan wawancara kepada mustahik untuk mengklasifikasikan rumah tangga mustahik sesuai kuadran CIBEST dan melihat indeks kemiskinan secara Islami menggunakan Model CIBEST (Center of Islamic Business and Economics Studies). Analisis logistik digunakan untuk menentukan faktor-faktor yang memengaruhi pergeseran rumah tangga mustahik dari kategori kuadran miskin menuju kuadran sejahtera.

\subsection{Indeks Kemiskinan Islami: CIBEST MODEL}

CIBEST Model adalah salah satu alat ukur yang dikembangkan oleh Beik dan Arsyianti (2015b). CIBEST Model tidak hanya mengukur hal-hal yang bersifat material (Material Value), tapi juga 
mengukur hal-hal yang bersifat spiritual (Spiritual Value). Perhitungan Material Value (MV), sebagaimana ditujukan oleh formula berikut ini:

$$
\mathrm{MV}=\sum_{i=1}^{n} P_{i} M_{i}
$$

Keterangan :

MV = Standar minimal kebutuhan material yang harus dipenuhi keluarga $(\mathrm{Rp}$

atau mata uang lain) atau disebut juga Garis Kemiskinan Material

$\mathrm{P}_{\mathrm{i}} \quad=$ Harga barang dan jasa (Rp atau mata uang lain)

$\mathrm{M}_{\mathrm{i}} \quad$ = Jumlah minimal barang dan jasa yang dibutuhkan

Pada penelitian kali ini, nilai MV yang digunakan berasal dari nilai Garis Kemiskinan yang dikeluarkan oleh BPS pada periode September 2013 karena data terbaru yang tersedia di BPS untuk wilayah Kota Bekasi adalah data tahun 2013, sehingga pada wilayah lainnya juga menggunakan tahun 2013. Garis Kemiskinan periode September 2013 di tiap wilayah JABOTABEK, yaitu:

1. Garis kemiskinan Kota Jakarta sebesar Rp 434322

2. Garis kemiskinan Kota Tangerang sebesar Rp 398513

3. Garis Kemiskinan Kota Bekasi sebesar Rp 361510

4. Garis Kemiskinan Kota Bogor sebesar Rp 271970

Garis kemiskinan perkapita tersebut dikalikan dengan jumlah anggota keluarga, sehingga menjadi nilai MV (Garis Kemiskinan Material).

Selanjutnya pemenuhan kebutuhan spiritual dihitung dari standar pemenuhan lima variabel, yaitu skor pelaksanaan ibadah shalat, zakat, puasa, skor lingkungan keluarga/rumah tangga, dan skor kebijakan pemerintah. Untuk menilai skor pada masing-masing variabel ini digunakan skala Likert antara 1 hingga 5. Berikut adalah indikator kebutuhan spiritual beserta skor dari skala Likert.

Tabel 1 Indikator kebutuhan spiritual

\begin{tabular}{|c|c|c|c|c|c|c|}
\hline \multirow[b]{2}{*}{ Variabel } & \multicolumn{5}{|c|}{ Skala Likert } & \multirow{2}{*}{$\begin{array}{c}\text { Standar } \\
\text { Kemiskinan }\end{array}$} \\
\hline & 1 & 2 & 3 & 4 & 5 & \\
\hline Shalat & $\begin{array}{l}\text { Melaran } \\
\text { g orang } \\
\text { lain } \\
\text { shalat }\end{array}$ & $\begin{array}{c}\text { Menolak } \\
\text { konsep } \\
\text { shalat }\end{array}$ & $\begin{array}{l}\text { Melaksana } \\
\text { kan shalat } \\
\text { wajib tidak } \\
\text { rutin }\end{array}$ & $\begin{array}{l}\text { Melaksanaka } \\
\text { n shalat } \\
\text { wajib rutin } \\
\text { tapi tidak } \\
\text { selalu } \\
\text { berjamaah }\end{array}$ & $\begin{array}{l}\text { Melaksanakan } \\
\text { shalat wajib } \\
\text { rutin } \\
\text { berjamaah dan } \\
\text { melakukan } \\
\text { shalat sunnah }\end{array}$ & \\
\hline Puasa & $\begin{array}{l}\text { Melaran } \\
\text { g orang } \\
\text { lain } \\
\text { berpuas } \\
\text { a }\end{array}$ & $\begin{array}{c}\text { Menolak } \\
\text { konsep } \\
\text { puasa }\end{array}$ & $\begin{array}{l}\text { Melaksana } \\
\text { kan puasa } \\
\text { wajib tidak } \\
\text { penuh }\end{array}$ & $\begin{array}{c}\text { Hanya } \\
\text { melaksanaka } \\
\text { n puasa wajib } \\
\text { secara penuh }\end{array}$ & $\begin{array}{c}\text { Melaksanakan } \\
\text { puasa wajib } \\
\text { dan puasa } \\
\text { sunnah }\end{array}$ & $\begin{array}{l}\text { Skor rata-rata } \\
\text { untuk } \\
\text { keluarga yang }\end{array}$ \\
\hline $\begin{array}{c}\text { Zakat, } \\
\text { Infak, dan } \\
\text { Sedekah }\end{array}$ & $\begin{array}{l}\text { Melaran } \\
\text { g orang } \\
\text { lain } \\
\text { berzakat } \\
\text { dan } \\
\text { infak }\end{array}$ & $\begin{array}{c}\text { Menolak } \\
\text { zakat } \\
\text { dan } \\
\text { infak }\end{array}$ & $\begin{array}{c}\text { Tidak } \\
\text { pernah } \\
\text { berinfak } \\
\text { walau } \\
\text { sekali } \\
\text { dalam } \\
\text { setahun }\end{array}$ & $\begin{array}{c}\text { Membayar } \\
\text { zakat fitrah } \\
\text { dan zakat } \\
\text { harta }\end{array}$ & $\begin{array}{c}\text { Membayar } \\
\text { zakat fitrah, } \\
\text { zakat harta dan } \\
\text { infak/sedekah }\end{array}$ & $\begin{array}{c}\text { secara } \\
\text { spiritual } \\
\text { miskin adalah } \\
3 \\
(\mathbf{S V}=\mathbf{3})\end{array}$ \\
\hline $\begin{array}{l}\text { Lingkung } \\
\text { an } \\
\text { Keluarga }\end{array}$ & $\begin{array}{l}\text { Melaran } \\
\mathrm{g} \\
\text { anggota }\end{array}$ & $\begin{array}{c}\text { Menolak } \\
\text { pelaksan } \\
\text { a-an } \\
\text { ibadah }\end{array}$ & $\begin{array}{c}\text { Mengangga } \\
\text { p ibadah } \\
\text { urusan } \\
\text { pribadi }\end{array}$ & $\begin{array}{c}\text { Mendukung } \\
\text { ibadah } \\
\text { anggota } \\
\text { keluarga }\end{array}$ & $\begin{array}{l}\text { Membangun } \\
\text { suasana } \\
\text { kelurga yang } \\
\text { mendukung }\end{array}$ & \\
\hline
\end{tabular}




\begin{tabular}{|c|c|c|c|c|c|c|}
\hline \multirow[b]{2}{*}{ Variabel } & \multicolumn{5}{|c|}{ Skala Likert } & \multirow{2}{*}{$\begin{array}{c}\text { Standar } \\
\text { Kemiskinan }\end{array}$} \\
\hline & 1 & 2 & 3 & 4 & 5 & \\
\hline & $\begin{array}{l}\text { keluarga } \\
\text { ibadah }\end{array}$ & & $\begin{array}{l}\text { anggota } \\
\text { keluarga }\end{array}$ & & $\begin{array}{l}\text { ibadah secara } \\
\text { bersama-sama }\end{array}$ & \\
\hline $\begin{array}{c}\text { Kebijakan } \\
\text { Pemerinta } \\
\mathrm{h}\end{array}$ & $\begin{array}{l}\text { Melaran } \\
\text { g ibadah } \\
\text { untuk } \\
\text { setiap } \\
\text { keluarga }\end{array}$ & $\begin{array}{c}\text { Menolak } \\
\text { pelaksan } \\
\text { a-an } \\
\text { ibadah }\end{array}$ & $\begin{array}{l}\text { Mengangga } \\
\text { p ibadah } \\
\text { urusan } \\
\text { pribadi } \\
\text { masyarakat }\end{array}$ & $\begin{array}{l}\text { Mendukung } \\
\text { ibadah }\end{array}$ & $\begin{array}{l}\text { Menciptakan } \\
\text { lingkungan } \\
\text { yang kondusif } \\
\text { untuk ibadah }\end{array}$ & \\
\hline
\end{tabular}

Sumber: Beik dan Arsyianti (2015a)

Selanjutnya, jika Garis Kemiskinan Spiritual atau Spiritual Value (SV) bernilai sama dengan tiga, maka rumah tangga tersebut dapat dikategorikan miskin secara spiritual karena belum mampu memenuhi kebutuhan ibadah wajib.

Keterangan:

$$
\mathrm{H}_{\mathrm{i}}=\frac{V P+V f+V z+V h+V g}{5}
$$

$\mathrm{H}_{\mathrm{i}} \quad$ = skor aktual keluarga ke- $\mathrm{i}$

$\mathrm{Vp} \quad=$ skor shalat

$\mathrm{Vf} \quad=$ skor puasa

$\mathrm{Vz} \quad=$ skor zakat dan infak

$\mathrm{Vh} \quad=$ skor lingkungan keluarga

$\mathrm{Vg} \quad=$ skor kebijakan pemerintah

Dari perhitungan di atas, dapat diketahui berapa jumlah keluarga yang ada di masing-masing kuadran CIBEST dengan mengombinasikan nilai aktual MV dan SV (Tabel 2).

Tabel 2 Kuadran CIBEST

\begin{tabular}{ccc}
\hline Skor Aktual & $\leq$ Nilai $\boldsymbol{M V}$ & $>$ Nilai $\boldsymbol{M V}$ \\
\hline$>$ Nilai $\boldsymbol{S V}$ & Kaya spiritual, Miskin material & Kaya spiritual, Kaya material \\
& (Kuadran II) & (Kuadran I) \\
$\mathbf{S}$ Nilai $\boldsymbol{S V}$ & Miskin spiritual, Miskin material & Miskin spiritual, Kaya material \\
& (Kuadran IV) & (Kuadran III) \\
\hline
\end{tabular}

Sumber: Beik dan Arsyianti (2015a)

Dari hasil perhitungan formula dan kuadran CIBEST di atas, dapat dihitung indeks kesejahteraan (kuadran I), indeks kemiskinan material (kuadran II), indeks kemiskinan spiritual (kuadran III), Indeks kemiskinan absolut (kuadran IV). Menurut Beik dan Arsyianti (2015a), formula tersebut adalah:

1. Indeks kesejahteraan

Keterangan:

$$
\mathrm{W}=\frac{w}{N}
$$

$\mathrm{W} \quad=$ Indeks kesejahteraan; $0 \leq W \leq 1$

$\mathrm{w}=$ Jumlah keluarga sejahtera (kaya secara material dan spiritual)

$\mathrm{N} \quad=$ Jumlah populasi (jumlah keluarga yang diobservasi)

2. Indeks kemiskinan material

Keterangan:

$$
\operatorname{Pm}=\frac{M p}{N}
$$

$\mathrm{Pm} \quad=$ Indeks kemiskinan material; $0 \leq P m \leq 1$

$\mathrm{Mp} \quad=$ Jumlah keluarga yang miskin secara material namun kaya secara 


$$
\mathrm{N} \quad \begin{aligned}
& \text { spiritual } \\
& \text { Jumlah populasi (total keluarga yang diamati) }
\end{aligned}
$$

3. Indeks kemiskinan spiritual

Keterangan:

$$
\text { Ps }=\frac{S p}{N}
$$

Ps $\quad=$ Indeks kemiskinan spiritual; $0 \leq P s \leq 1$

Sp $\quad=$ Jumlah keluarga yang miskin secara spiritual namun kaya secara materil

$\mathrm{N} \quad=$ Jumlah populasi (total keluarga yang diamati)

4. Indeks kemiskinan absolut

Keterangan:

$$
\mathrm{Pa}=\frac{A p}{N}
$$

$\mathrm{Pa}=$ Indeks kemiskinan absolut; $0 \leq P a \leq 1$

Ap $\quad=$ Jumlah keluarga yang miskin secara spiritual maupun secara materil

$\mathrm{N} \quad=$ Jumlah populasi (total keluarga yang diamati)

\subsection{Analisis Regresi Logistik}

Metode logit digunakan untuk mengetahui faktor-faktor yang memengaruhi pergeseran rumah tangga mustahik dari kategori kuadran miskin menuju kuadran sejahtera pada kondisi setelah mustahik mendapatkan bantuan dana zakat oleh Rumah Zakat. Model logit yang digunakan adalah sebagai berikut:

$$
\operatorname{Ln}\left[\frac{P_{1}}{1-P_{1}}\right]=b_{0}+b_{1} X_{1}+b_{2} X_{2}+b_{i} X_{a}+\cdots+b_{7} X_{7}+e i
$$

Keterangan:

$\mathrm{P}_{\mathrm{i}} \quad$ : Probabilitas rumah tangga mustahik sejahtera

$1-\mathrm{P}_{\mathrm{i}} \quad$ : Probabilitas rumah tangga mustahik miskin

$b_{0} \quad$ : Konstanta atau intersep model garis regresi

$b_{i} \quad:$ Koefisien variabel ke-i $(\mathrm{i}=1 \ldots 7)$

$X_{1} \quad$ : Usia (tahun)

$X_{2}$ : Bantuan dana zakat produktif, sebagai dummy ( $1=$ bantuan dana zakat $\geq 707000$ rupiah dan $0=$ bantuan dana zakat $<707000$ rupiah) dan bantuan dana zakat konsumtif, sebagai dummy (1= bantuan dana zakat $\geq 384400$ rupiah dan $0=$ bantuan dana zakat $<384400$ rupiah)

$X_{3} \quad$ : Jumlah tanggungan (orang)

$X_{4} \quad$ : Pendidikan, sebagai dummy $(1=$ pendidikan terakhir $\geq$ SMA dan $0=$ pendidikan $<$ SMA $)$

$X_{5} \quad$ : Jenis kelamin, sebagai dummy $(1=$ laki-laki dan $0=$ perempuan $)$

$X_{6}$ : Pekerjaan, sebagai dummy $(1=$ pedagang, buruh, kuli, satpam, karyawan dan $0=i b u$ rumah tangga, pemulung)

$X_{7} \quad$ : Pendapatan penerima zakat produktif, sebagai dummy $(1=$ pendapatan per bulan $\geq 2215900$ rupiah dan $0=$ pendapatan per bulan < 2215900 rupiah) dan pendapatan penerima zakat konsumtif, sebagai dummy $(1=$ pendapatan per bulan $\geq 1495900$ rupiah dan $0=$ pendapatan per bulan $<1495900$ rupiah)

$e_{i} \quad$ : Galat 


\section{Hasil dan Pembahasan}

\subsection{Karakteristik Rumah Tangga Mustahik}

Responden dalam penelitian ini berjumlah 100 orang yang dibagi berdasarkan jenis kelamin, usia, status pernikahan, jumlah tanggungan, pendidikan, dan pekerjan. Data karakteristik kepala keluarga tersebut dapat dilihat pada Gambar 1.

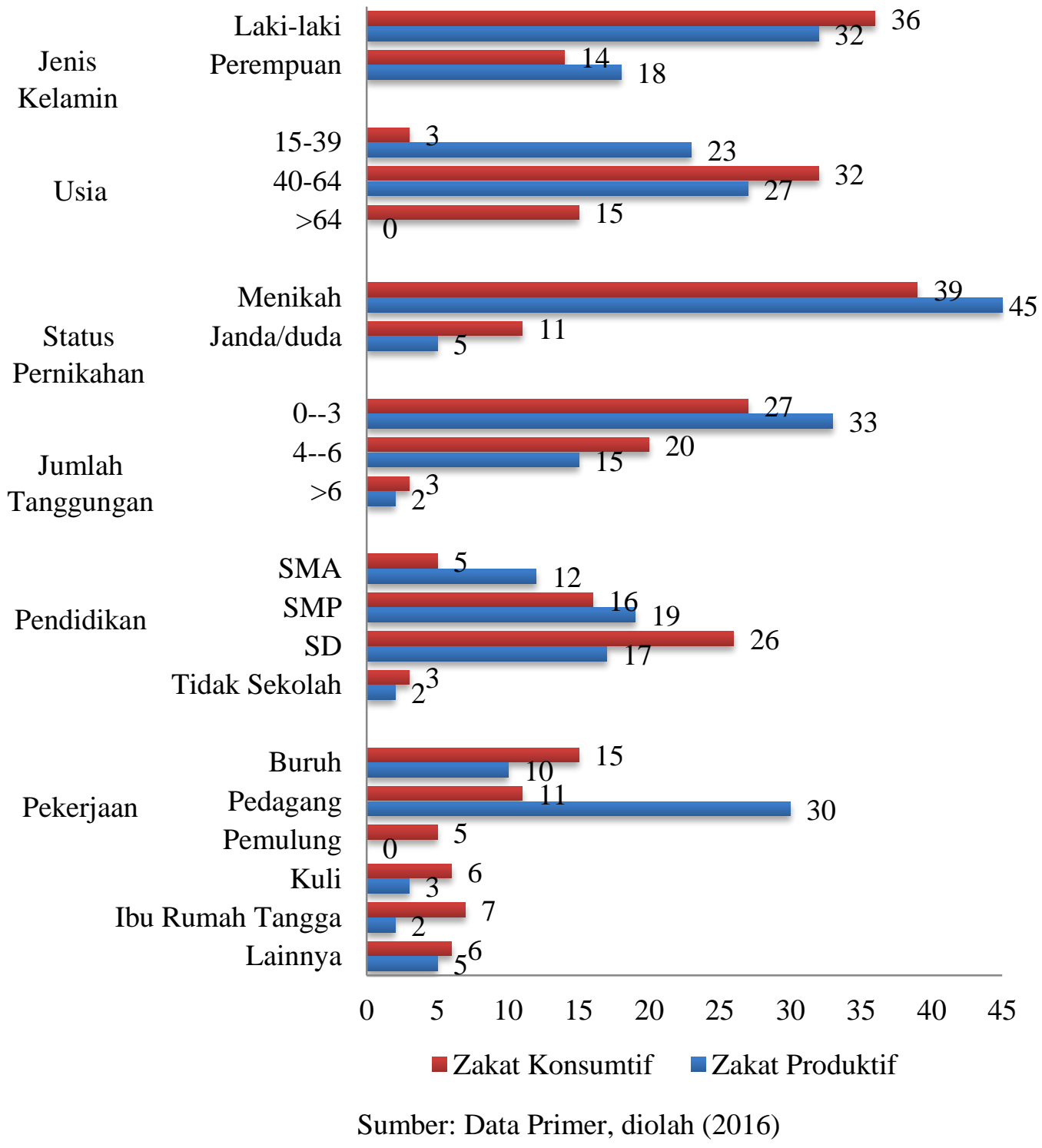

\section{Gambar 1 Karakteristik kepala rumah tangga mustahik}

Gambar 1 menunjukkan bahwa mayoritas mustahik, baik mustahik zakat konsumtif maupun zakat produktif, berjenis kelamin laki-laki, berusia 40-64 tahun, sudah menikah, dan memiliki jumlah tanggungan kurang dari 4 orang. Mayoritas responden berpendidikan SD dan bekerja sebagai pedagang atau buruh.

\subsubsection{Rata-rata Besar Bantuan Dana Zakat}

Besar bantuan dana zakat adalah bantuan dana zakat terakhir yang diberikan oleh Rumah Zakat periode tahun 2015-2016 kepada mustahik. Sumber pendapatannya beragam, yaitu dari hasil gaji, upah, 
berdagang, dan lainnya. Rata-rata pendapatan rumah tangga mustahik dijelaskan pada Tabel 3 berikut ini:

Tabel 3 Rata-rata besar bantuan dana zakat

\begin{tabular}{lrr}
\hline \multicolumn{1}{c}{ Indikator } & Mustahik zakat produktif & \multicolumn{1}{c}{ Mustahik zakat konsumtif } \\
\hline $\begin{array}{l}\text { Rata-rata besar bantuan } \\
\text { dana zakat }\end{array}$ & 707000 & 384400 \\
\hline Sumber: Data Primer, diolah (2016) & & \\
\hline
\end{tabular}

Tabel 3 menunjukkan bahwa rata-rata besar bantuan dana zakat yang diperoleh oleh mustahik zakat produktif adalah sebesar Rp 707 000, sedangkan dengan rata-rata besar bantuan yang diperoleh oleh mustahik zakat konsumtif adalah sebesar Rp 384400.

\subsubsection{Rata-Rata Pendapatan Rumah Tangga Mustahik}

Pendapatan yang diperoleh oleh mustahik adalah pendapatan pokok bulanan dan pendapatan tambahan dari jumlah bantuan dana zakat terakhir yang diterima oleh mustahik. Sumber pendapatan pokok beragam, yaitu dari hasil gaji, upah, berdagang, dan lainnya. Rata-rata pendapatan rumah tangga mustahik ditunjukkan pada Tabel 4.

Tabel 4 Rata-rata pendapatan rumah tangga mustahik

\begin{tabular}{lrr}
\hline & \multicolumn{2}{c}{ Rata-rata pendapatan mustahik } \\
\cline { 2 - 3 } \multicolumn{1}{c}{ Indikator } & zakat produktif & zakat konsumtif \\
\hline Sebelum bantuan zakat & 2215900 & 1495900 \\
Sesudah bantuan zakat & 2932500 & 1696100 \\
Persentase (\%) & 32.33 & 13.38 \\
\hline
\end{tabular}

Sumber: Data Primer, diolah (2016)

Tabel 4 menunjukkan bahwa terjadi peningkatan rata-rata pendapatan mustahik zakat produktif dari Rp 2215900 menjadi Rp 2932500 per bulannya atau meningkat sebesar 32.33\%, sedangkan pendapatan mustahik zakat konsumtif meningkat dari Rp 1495900 menjadi Rp 1696100 per bulannya atau meningkat sebesar $13.38 \%$. Berdasarkan hal ini, terlihat bahwa zakat produktif dan zakat konsumtif sama-sama dapat meningkatkan pendapatan mustahik. Zakat produktif memberikan dampak yang lebih besar terhadap peningkatan pendapatan mustahik dibandingkan dengan zakat konsumtif. Hal ini disebabkan oleh rata-rata pendapatan tambahan (bantuan dana zakat) yang diberikan kepada penerima zakat produktif lebih besar dibandingkan dengan rata-rata pendapatan tambahan (bantuan dana zakat) yang diberikan pada penerima zakat konsumtif, hal ini sesuai dengan Tabel 3.

\subsection{Hasil Analisis Rumah Tangga Mustahik Berdasarkan Kuadran dan Indeks Kemiskinan Islam menggunakan CIBEST Model}

\subsubsection{Analisis Kuadran CIBEST pada Tingkat Kemiskinan Rumah Tangga Mustahik Sebelum Adanya Bantuan Dana Zakat}

Kuadran CIBEST terdiri atas empat kuadran, yaitu kuadran I adalah kategori sejahtera, kuadran II adalah kategori miskin material, kuadran III adalah kategori miskin spiritual, dan kuadran IV adalah kategori miskin absolut. Berdasarkan data yang sudah dikumpulkan melalui kuesioner dan wawancara dengan mustahik dengan melihat nilai Material Value (MV) dan nilai Spiritual Value (SV) yang berbeda-beda pada tiap rumah tangga mustahik, didapatkan hasil yang ditampilkan pada Tabel 5. 
Tabel 5 Klasifikasi rumah tangga berdasarkan kuadran CIBEST sebelum dan sesudah adanya bantuan zakat

\begin{tabular}{lcccc}
\hline \multicolumn{1}{c}{ Indikator } & \multicolumn{2}{c}{ Mustahik zakat produktif } & \multicolumn{2}{c}{ Mustahik zakat konsumtif } \\
& Sebelum & Sesudah & Sebelum & Sesudah \\
\hline \hline Kuadran I & 31 & 38 & 12 & 16 \\
Kuadran II & 14 & 12 & 22 & 20 \\
Kuadran III & 3 & 0 & 7 & 6 \\
Kuadran IV & 2 & 0 & 9 & 8 \\
\hline Jumlah & 50 & 50 & 50 & 50 \\
\hline
\end{tabular}

Sumber: Data primer, diolah (2016)

Tabel 5 menggambarkan bahwa sesudah adanya bantuan zakat, terjadi peningkatan jumlah mustahik pada kuadran I, yaitu dari 31 menjadi 38 mustahik untuk zakat produktif, dan dari 12 menjadi 16 untuk zakat konsumtif. Kenaikan jumlah mustahik ini menunjukkan bahwa mustahik yang sejahtera semakin banyak. Sementara itu, pada kuadaran lainnya terjadi penurunan jumlah mustahik dari 14 menjadi 12 untuk zakat produktif dan dari 22 menjadi 20 untuk zakat konsumtif pada kuadran II, dari 3 menjadi 0 untuk zakat produktif dan 7 menjadi 6 untuk zakat konsumtif pada kuadran III, serta dari 2 menjadi 0 untuk zakat produktif dan dari 9 menjadi 8 untuk zakat konsumtif pada kuadran IV. Penurunan jumlah mustahik ini menunjukkan bahwa jumlah mustahik yang miskin semakin sedikit. Zakat produktif dan zakat konsumtif sama-sama dapat memberikan dampak positif bagi peningkatan kesejahteraan material dan spiritual mustahik.

\subsubsection{Analisis Indeks Kemiskinan Rumah Tangga Mustahik (CIBEST MODEL)}

Setelah diketahui masing-masing jumlah rumah tangga mustahik untuk tiap kuadran, didapatkan hasil perhitungan indeks kemiskinan. Hasil perhitungan indeks kemiskinan ini juga dilakukan melalui pendekatan pada kondisi rumah tangga mustahik sebelum dan sesudah mendapatkan bantuan dana zakat Rumah Zakat (Tabel 6).

Tabel 6 Hasil indeks kemiskinan Islam (sebelum dan sesudah ada dana bantuan zakat)

\begin{tabular}{|c|c|c|c|c|c|c|}
\hline \multirow{2}{*}{$\begin{array}{l}\text { Indeks } \\
\text { Kemiskinan } \\
\text { Islam }\end{array}$} & \multicolumn{3}{|c|}{ Zakat Produktif } & \multicolumn{3}{|c|}{ Zakat Konsumtif } \\
\hline & Sebelum & Sesudah & Perubahan & Sebelum & Sesudah & Perubahan \\
\hline Indeks & & & & & & \\
\hline Kesejahteraan & 0.31 & 0.38 & 0.07 & 0.12 & 0.16 & 0.04 \\
\hline $\begin{array}{l}\text { Indeks } \\
\text { Kemiskinan } \\
\text { Material }\end{array}$ & 0.14 & 0.12 & -0.02 & 0.22 & 0.20 & -0.02 \\
\hline $\begin{array}{l}\text { Indeks } \\
\text { Kemiskinan } \\
\text { Spiritual }\end{array}$ & 0.03 & 0 & -0.03 & 0.07 & 0.06 & -0.01 \\
\hline $\begin{array}{l}\text { Indeks } \\
\text { Kemiskinan } \\
\text { Absolut }\end{array}$ & 0.02 & 0 & -0.02 & 0.09 & 0.08 & -0.01 \\
\hline
\end{tabular}

Sumber: Data primer, diolah (2016)

Berdasarkan Tabel 6, diketahui bahwa terjadi peningkatan indeks kesejahteraan rumah tangga mustahik sebesar 0.07 untuk zakat produktif dan 0.04 untuk zakat konsumtif. Kedua jenis penyaluran zakat ini sama-sama memberikan dampak yang positif terhadap peningkatan kesejahteraan mustahik. Peran zakat produktif lebih kuat dibandingkan zakat konsumtif dalam peningkatan kesejahteraan mustahik. Hal ini disebabkan amil zakat tidak hanya memberikan zakat produktif, tapi juga pendampingan usaha terhadap mustahik. Pendampingan usaha di sini tidak hanya membahas masalah usaha, tapi juga 
memberikan pendidikan agama kepada para mustahik, sehingga mustahik menjadi lebih memahami agamanya. Pemahaman agama ini memberikan efek positif bagi peningkatan kesejahteraan spiritual.

Hal ini sesuai dengan teori bahwa ketaqwaan akan memberikan solusi bagi orang miskin dan Allah akan memberikan rezeki dari jalan yang tidak disangka-sangka (QS. At-Thalaq: 2-3). Hal ini juga sesuai dengan penelitian Pratama (2015) bahwa rumah tangga yang menyertakan nilai-nilai Islam dalam aktivitasnya akan bermuara pada pemenuhan kebutuhan pokok yang mengandung maslahah. Zakat produktif dan zakat konsumtif sama-sama menurunkan Indeks kemiskinan sebesar 0.02. Hal ini menunjukkan bahwa peran zakat produktif dan zakat konsumtif memiliki kekuatan yang sama dalam menurunkan indeks kemiskinan material. Penurunan indeks kemiskinan material ini juga sesuai dengan hasil penelitian-penelitian terdahulu terkait dampak zakat terhadap kemiskinan.

Indeks kemiskinan spiritual turun 0.03 untuk zakat produktif dan turun 0.01 untuk zakat konsumtif. Hal ini menunjukkan bahwa zakat produktif dan zakat konsumtif sama-sama dapat menurunkan kemiskinan spiritual mustahik. Terlihat bahwa zakat produktif lebih kuat menurunkan indeks kemiskinan spiritual dibandingkan dengan zakat konsumtif. Indeks kemiskinan absolut turun 0.02 untuk zakat produktif dan turun 0.01 untuk zakat konsumtif. Hal ini juga menunjukkan bahwa zakat produktif dan juga dapat menurunkan indeks kemiskinan absolut mustahik dan peran zakat produktif lebih kuat dibandingkan zakat konsumtif dimana zakat produktif mampu menekan indeks kemiskinan absolut sampai bernilai 0 , sedangkan zakat konsumtif masih menyisakan indeks sebesar 0.08 .

Berdasarkan hal ini terlihat bahwa terdapat kenaikan indeks kesejahteraan dan penurunan semua indeks kemiskinan setelah adanya bantuan zakat. Dapat dinyatakan bahwa zakat, selain dapat meningkatkan kesejahteraan, juga dapat menurunkan kemiskinan. Meski sama-sama dapat menurunkan kemiskinan, peran zakat produktif terlihat lebih unggul dalam meningkatkan kesejahteraan dibandingkan zakat konsumtif. Meski belum dapat memindahkan semua mustahik ke dalam kuadran I, zakat produkif mampu menghapus semua mustahik yang berada di dalam kuadran III dan IV, sehingga mustahik hanya ada di kuadran I (sejahtera) dan di kuadran II (miskin material).

\subsection{Faktor-faktor yang Memengaruhi Pergeseran Rumah Tangga Mustahik dari Kategori Kuadran Miskin Menuju Kuadran Sejahtera Menggunakan Analisis Logit}

Menurut Clasificatoin test, Omnimbus test, Hosmer Lemeshow test, dan Model Sumary test, Model ini sudah memenuhi syarat, sehingga layak untuk dijadikan model dalam suatu analisis. Faktor-faktor yang diduga memengaruhi keluarnya rumah tangga mustahik dari kategori kuadran miskin menuju kuadran sejahtera yaitu usia, bantuan zakat, jumlah tanggungan, pendidikan, jenis kelamin, pekerjaan, dan pendapatan. Variabel yang akan dilihat terdiri dari dua kemungkinan, yaitu rumah tangga mustahik sejahtera $(\mathrm{Y}=1)$ atau rumah tangga mustahik miskin $(\mathrm{Y}=0)$.

Tabel 7 Faktor-faktor yang memengaruhi pergeseran rumah tangga mustahik dari kategori kuadran miskin menuju kuadran sejahtera

\begin{tabular}{llclc}
\hline \multirow{2}{*}{ Variabel } & \multicolumn{2}{c}{ Zakat Produktif } & \multicolumn{2}{c}{ Zakat Konsumtif } \\
\cline { 2 - 5 } & Sig. & $\begin{array}{c}\text { Odd Ratio } \\
\text { Exp(B) }\end{array}$ & Sig. & $\begin{array}{c}\text { Odd Ratio } \\
\text { Exp(B) }\end{array}$ \\
\hline Bantuan Zakat & 0.808 & 1.383 & 0.310 & 4.099 \\
Jumlah Tanggungan & $0.007 * * *$ & 0.227 & $0.021^{* *}$ & 0.018 \\
Pendidikan & 0.595 & 2.322 & $0.061^{*}$ & $\mathbf{8 7 . 6 9 6}$ \\
Jenis Kelamin & 0.317 & 4.694 & 0.190 & 19.558 \\
Pekerjaan & $0.009^{* * *}$ & $\mathbf{3 7 . 6 6 4}$ & 0.176 & 39.095 \\
Pendapatan & $0.040^{* *}$ & 17.468 & $0.097 *$ & 60.769 \\
\hline
\end{tabular}

Sumber : Data primer, diolah (2016)

Keterangan : ***signifikan pada taraf nyata $1 \%$

** signifikan pada taraf nyata $5 \%$

* signifikan pada taraf nyata $10 \%$

Jurnal Al-Muzara'ah Vol.4, No.1, 2016

(ISSN p: 2337-6333; e: 2355-4363) 
Berdasarkan Tabel 7, dapat dilihat bahwa variabel independen yang berpengaruh signifikan terhadap variabel dependen pada zakat produktif adalah jumlah tanggungan, pekerjaan, dan pendapatan, sedangkan pada zakat konsumtif variabel independen yang berpengaruh nyata terhadap variabel dependen adalah usia, jumlah tanggungan, pendidikan, dan pendapatan. Hal ini dikarenakan nilai koefisien signifikansi variabelnya lebih kecil dari taraf nyata. Setiap variabel independet memberikan peluang yang berbeda terhadap pergeseran rumah tangga mustahik dari kategori kuadran miskin menuju kuadran sejahtera. Besarnya peluang dapat diketahui dengan menginterpretasikan nilai odds ratio pada masing-masing variabel independent dan pengaruhnya dapat dilihat berdasarkan nilai koefisien (B).

\subsubsection{Zakat Produktif}

Variabel jumlah tanggungan memiliki odd ratio sebesar 0.227 dan berpengaruh negatif. Hal ini berarti bahwa peluang rumah tangga mustahik yang memiliki jumah tanggungan lebih dari satu orang memungkinkan rumah tangga mustahik untuk keluar dari kategori kuadran miskin menuju kuadran sejahtera 0.227 kali, ceteris paribus. Variabel pekerjaan memiliki odd ratio sebesar 37.664 dan berpengaruh positif. Hal ini berarti bahwa kepala rumah tangga mustahik yang memiliki profesi sebagai pedagang memiliki peluang 37.664 kali untuk keluar dari kategori kuadran miskin menuju kuadran sejahtera dibandingkan dengan kepala rumah tangga mustahik yang memiliki profesi selain pedagang, ceteris paribus. Hal ini sesuai dengan konsep ekonomi Islam bahwa sebagian besar rezeki didapatkan melalui berdagang.

Variabel pendapatan memiliki odd ratio sebesar 17.468 dan berpengaruh positif. Hal ini berarti bahwa rumah tangga mustahik yang berpendapatan lebih dari atau sama dengan 2215900 rupiah per bulan memiliki peluang 17.468 kali untuk keluar dari kategori kuadran miskin menuju kuadran sejahtera dibandingkan dengan rumah tangga mustahik yang berpendapatan kurang dari 2215900 rupiah per bulan, ceteris paribus. Hal ini dapat dengan mudah dipahami bahwa yang berpenghasilan lebih tinggi sudah sewajarnya lebih mudah keluar dari kemiskinan daripada yang berpenghasilan lebih rendah.

Berdasarkan uraian di atas diketahui bahwa variabel yang paling berpengaruh positif adalah variabel pekerjaan. Variabel pekerjaan sangat menonjol dibandingkan dengan variabel lainnya dalam hal peningkatan kesejahteraan mustahik. hal ini bermakna bahwa variabel pekerjaan adalah variabel utama yang harus diupayakan jika ingin mustahik terlepas dari kemiskinan. Hal ini sesuai dengan konsep Islam bahwa salah satu cara yang paling efektif dalam menanggulangi kemiskinan adalah dengan pembukaan lapangan kerja. Qardhawi (2005) menukil dua perkataan sahabat Rasulullah tentang buruknya pengangguran. Abdullah bin Zubair berkata, "Seburuk-buruknya sesuatu yang ada di dunia ini adalah pengangguran." Ali bin Abi Thalib berkata, "Mencari nafkah yang diragukan kehalalannya masih lebih baik dibandingkan bermalas-malasan.".

\subsubsection{Zakat Konsumtif}

Variabel jumlah tanggungan memiliki odd ratio sebesar 0.018 dan berpengaruh negatif. Hal ini berarti bahwa peluang rumah tangga mustahik dengan jumlah tanggungan lebih dari satu orang memungkinkan rumah tangga mustahik untuk keluar dari kategori kuadran miskin menuju kuadran sejahtera 0.018 kali, ceteris parius.

Variabel pendidikan memiliki odd ratio sebesar 87.696 dan berpengaruh positif. Hal ini berarti bahwa kepala rumah tangga mustahik yang berpendidikan SMA atau lebih memiliki peluang 87.696 kali untuk keluar dari kategori kuadran miskin menuju kuadran sejahtera dibandingkan dengan kepala rumah tangga mustahik yang berpendidikan kurang dari SMA, ceteris paribus. Variabel pendapatan memiliki odd ratio sebesar $\mathbf{6 0 . 7 6 9}$ dan berpengaruh positif. Hal ini berarti bahwa rumah tangga mustahik yang berpendapatan lebih dari atau sama dengan 1495900 rupiah per bulan memiliki peluang 60.769 kali 
untuk keluar dari kategori kuadran miskin menuju kuadran sejahtera dibandingkan dengan rumah tangga mustahik yang berpendapatan kurang dari 1495900 rupiah per bulan, ceteris paribus.

Berdasarkan uraian di atas, dari ke-empat variabel yang berpengaruh signfikan terhadap peningkatan kesejahteraan mustahik, terdapat dua variabel yang sangat menonjol dalam memengaruhi kesejahteraan mustahik, yaitu variabel pendidikan dan pekerjaan. Mustahik yang berpendidikan SMA atau lebih tinggi mempunyai peluang yang lebih besar untuk mencapai level sejahtera dibandingkan dengan mustahik yang berpendidikan lebih rendah dari SMA. Demikian halnya dengan mustahik yang bekerja memiliki peluang yang lebih besar menjadi sejahtera dibandingkan dengan mustahik yang tidak bekerja. Mustahik yang lebih berpendidikan dan memiliki pekerjaan berpeluang besar menjadi sejahtera, hal ini disebabkan mustahik yang terdidik dan memiliki pekerjaan memiliki kesempatan yang lebih luas untuk mencari dan mendapatkan penghasilan dibandingkan dengan mustahik yang bependidikan rendah dan tidak bekerja.

\section{Simpulan dan Saran}

\subsection{Simpulan}

Berdasarkan hasil penelitian, dapat disimpulkan bahwa zakat produktif dan zakat konsumtif mampu meningkatkan kesejahteraan sekaligus menurunkan kemiskinan mustahik. Namun demikian, zakat produktif lebih mampu mengurangi kemiskinan dibanding zakat konsumtif. Hal ini disebabkan pemberian zakat produktif oleh amil kepada mustahik selalu diiringi dengan pendampingan usaha yang tidak hanya memberikan informasi mengenai bagaimana cara berbisnis yang baik, tapi juga memberikan bagaimana cara beragama yang benar sesuai dengan ketentuan syariat Islam. Pendidikan agama yang diberikan amil berperan penting dalam meningkatkan pemahaman dan kesadaran beragama mustahik, dan hal ini berperan penting dalam mengeluarkan mustahik dari kemiskinan spiritual.

Faktor-faktor yang berpengaruh secara positif dan signifikan terhadap rumah tangga mustahik untuk keluar dari kategori kuadran miskin menuju kuadran sejahtera setelah adanya bantuan dana zakat produktif adalah pendapatan rumah tangga mustahik dan pekerjaan kepala rumah tangga, sedangkan pada zakat konsumtif faktor-faktor yang berpengaruh terhadap hal tersebut adalah pendidikan kepala rumah tangga dan pendapatan rumah tangga mustahik. Faktor pendapatan sama-sama berpengaruh positif terhadap kedua cara penyaluran zakat tersebut.

\subsection{Saran}

Penyaluran zakat baik secara produktif maupun konsumtif dapat dilanjutkan dan ditingkatkan karena terbukti dapat meningkatkan kesejahteraan sekaligus menurunkan kemiskinan masyarakat. Pendidikan, pekerjaan, dan pendapatan merupakan faktor-faktor yang berpengaruh positif dan signifikan terhadap pengentasan kemiskinan mustahik. Oleh sebab itu, upaya perbaikan dan peningkatan kuantitas dan kualitas faktor-faktor tersebut perlu senantiasa ditingkatkan oleh pihak-pihak terkait. Program wajib belajar hingga SMA perlu terus diterapkan dan ditingkatkan hingga mencapai perguruan tinggi. Pemerintah bersama-sama dengan organisasi pengelola zakat juga perlu memperluas lapangan kerja dan akses modal.

\section{Daftar Pustaka}

Adianti G. 2005. Analisis Faktor-faktor yang Mempengaruhi Kemiskinan di DKI Jakarta (Studi Komparatif di Permukiman Kumuh dan Tidak Kumuh). Tesis. Bogor (ID): Institut Pertanian Bogor. 
Anriani. 2010. BAZ Kota Bogor dan pengentasan kemiskinan. Jurnal Ekonomi Islam Republika: 29 Juli 2010.

[BAZNAS]. Badan Zakat Nasional. 2011. Potensi Zakat 2011. [internet]. [diunduh 15 April 2016]. Tersedia pada: http://pusat.baznas.go.id.

Beik IS. 2009. Analisis peran zakat dalam mengurangi kemiskinan: studi kasus Dompet Dhuafa Republika. Institut Manajemen Zakat: Jurnal Pemikiran dan Gagasan Vol II 2009.

Beik IS, Arsyianti LD. 2015a. Construction of CIIBEST model as measurement of poverty and walfare indices from Islamic perspective. Al-Iqtishad Vol VII No 1.

Beik IS, Arsyianti LD. 2015b. Ekonomi Pembangunan Syariah. Bogor (ID): IPB Press.

[BPS] Badan Pusat Statistik. 2016. Jumlah Penduduk Miskin, Persentase Penduduk Miskin, dan Indeks Gini di Indonesia Tahun 2011-2015. [internet]. [diunduh pada 15 Maret 2016]. Tersedia pada: http://www.bps.go.id.

[Depag] Departemen Agama RI. 2002. Mushaf Al-Qur'an Terjemah. Jakarta (ID): Pena Pundi Aksara. El Ayyubi S, Lubis D. 2015. Filosofi Ekonomi Syariah. Bogor (ID): IPB Press.

Hartoyo S dan Purnamasari N. 2010. Pengentasan kemiskinan berbasis zakat: studi kasus di Garut. Jurnal Ekonomi Islam Republika: 29 Juli 2010.

Nicham S. 2012. Pembagian Zakat Konsumtif dan Produktif Bagi Mustahik Zakat (Studi Kasus Pembagian Zakat di Bapelurzam Daerah Kendal). Skripsi. Semarang (ID): IAIN Walisongo.

Pratama C. 2015. Pendayagunaan Zakat Produktif dalam Mengurangi Kemiskinan (CIBEST Model) Studi Kasus: Pendayagunaan Zakat Produktif Terhadap Rumah Tangga Mustahik oleh PT.Masyarakat Mandiri Dompet Dhuafa). Skripsi. Bogor (ID): Institut Pertanian Bogor.

Qardhawi, Y. 2005. Spektrum Zakat dalam Membangun Ekonomi Kerakyatan. Jakarta (ID): Zikrul Hakim.

Qardhawi Y. 2011. Hukum Zakat. Bogor (ID): Pustaka Litera AntarNusa.

Rosmawati R. 2014. Pengembangan potensi dana zakat produktif melalui Lembaga Amil Zakat (LAZ) untuk meningkatkan kesejahteraan masyarakat. Padjajaran Jurnal Ilmu Hukum 1 (1) : 175-191.

Siswi N. 2016. Analisis peran Lembaga Amil Zakat untuk menanggulangi kemiskinan di Kota Malang (studi pada Yayasan Dana Sosial Al-Falah). Jurnal Ilmiah Mahasiswa FEB Universitas Brawijaya Vol 4 No 2 tahun 2015/2016.

Tsani T. 2010. Mengentaskan kemiskinan dan kesenjangan di Lampung Selatan. Jurnal Ekonomi Islam Republika: 26 Juli 2010.

Wibisono Y. 2015. Mengelola Zakat Indonesia: Diskursus Pengelolaan Zakat Nasional dari Rezim UU No 38 tahun 1999 ke Rezim UU No 23 tahun 2011. Jakarta (ID): Prenada Media. 